\title{
Beak Trimming Methods and Their Effect on the Performance and Egg Quality of Japanese Quails (Coturnix japonica) During Lay
}

- Author(s)
Pizzolante $\mathrm{CC}^{1}$
Garcia EA
Saldanha ESPB ${ }^{1}$
Laganá $\mathrm{C}^{1}$
Faitarone ABG
Souza HBA
Pelicia K
1 Researchers of Agência Paulista de
Tecnologia dos Agronegócios Regional -
APTA.
2 Professor of the Deaprtment of Animal
Production of FM VZ/UNESP. Botucatu
Campus, SP.
3 Students of the Post-Graduation in Animal
Science of FM VZ/UNESP. Botucatu Campus,
SP.
4 Professor of the Department of Technology
of FCAV/UNESP. Jaboticabal Campus, SP.

Mail Address

Carla Cachoni Pizzolante

Agência Paulista de Tecnologia dos

Agronegócios Regional - APTA.

CP 09

17.380-000. Brotas, SP, Brasil.

E-mail: carla@aptaregional.sp.gov.br

\section{Keywords}

Age, beak trimming, feathering, performance, quails.

\section{INTRODUCTION}

A total number of 720 Japanese quail females, reared under identical management conditions, and receiving feed and water ad libitum, was used. Quails were housed and reared from 1-35 days of age in litter pens in a rearing house, and then were transferred to a quail layer house. This study aimed at verifying if different beak trimming method could optimize egg production and quality by reducing stress and cannibalism among birds. A completely randomized experimental design was used, with six treatments in a $2 \times 3$ factorial arrangement, with two beak trimming ages (14 and 21 days) and three beak trimming variants (non-trimmed, $1 / 3$ of the beak trimmed, or $1 / 2$ of the beak trimmed), with 6 replicates of 20 birds each. Performance was evaluated by feed intake, percentage of lay, egg mass, feed conversion ratio per dozen eggs and per kg eggs, and mortality. Performance was influenced by beak trimming variant, with the best results obtained by birds with intact beaks and those with $1 / 3$ of the beak trimmed. Better specific gravity was observed in quails submitted to beak trimming at 21 days of age, whereas the other egg quality parameters did not present significant results. Based on the results obtained in the present study, it is recommended to submit quails to beak trimming either at 14 or 21 days of age.

\section{INTRODUCTION}

The expansion of quail production in Brazil, currently established at industrial level, must be highlighted due to the generation of jobs, the use of small areas, the need of low investments, the fast return on investments, as well as a animal protein source.

Beak trimming is considered as necessary as a routine management practice in commercial layer production, aiming at the prevention of cannibalism and at reducing social stress. According to Cloutier et al. (2000), beak trimming is the main method used to prevent feather pecking and cannibalism in the poultry industry. How ever, its use is still controversial in quail production. Beak trimming is condemned by environmentalists, which perceive it as a painful mutilation. In addition, feed intake is impaired during the days immediately after beak trimming (Gentle, 1986).

On the other hand, producers consider this practice an essential procedure in young birds, in order to reduce feather pecking and cannibalism later, thereby improving performance, and positively contributing to bird welfare.

According to Hughes \& Gentle (1995), beak trimming is indicating in some cases, such as environmental factors (light intensity, environmental temperature, type of poultry house), social factors (flock size and density), and genetic lines (more or less aggressive birds). Cunningham (1992) adds that, although beak trimming is usually considered as a stressful 
procedure, it promotes benefits, such as the reduction of feather pecking and cannibalism, demonstrating the importance of this procedure in layer production.

Economic losses caused by feather pecking are due to the fact that feather removal impairs the maintenance of body temperature, leading to an increase in feed intake (Leeson \& Morrison, 1978), which can be more than $27 \%$ of the usual intake, according to Tauson \& Svensson, 1980. One of the main losses caused by cannibalism is an increase in the incidence of egg pecking.

Literature reports a reduction in feed intake and an improvement of feed conversion ratio in layers submitted to beak trimming. Even when there are no cannibalism problems, beak trimming is beneficial, resulting in lower mortality and better feed efficiency and social status.

Araújo (1997) evaluated the performance and cannibalism frequency of layers not submitted to beak trimming or submitted to mild beak trimming (of $1 / 3$ of the beak) or severe beak trimming ( $1 / 2$ of the beak), and found cannibalism incidences of $13 \%, 4 \%$, and $0 \%$, respectively, in the period of up to 13 weeks of age. A second beak trimming was performed at 13 weeks of age, and the author observed lower feed intake and body weight at 17 weeks of age in birds submitted to severe beak trimming $(5 \mathrm{~mm}$ from the nostril). Mild beak trimming was performed at $7 \mathrm{~mm}$ from the nostril. In birds submitted to severe and mild beak trimming, feed intake decreased 48 and $36 \%$, and body weight loss was 19.5 and $12 \%$, respectively.

Beak trimming reduces egg pecking, and therefore, the incidence of broken eggs (Buxadé Carbó, 1987). In addition, birds with intact beaks present higher stress and social tension levels as compared to beak-trimmed birds (North \& Bell, 1993). An increase in stress levels induce an increase in adrenaline, oxytocin, and vasopressin levels, which may increase oviduct contraction, causing the egg undergoing calcification to be expelled, therefore increasing the incidence of eggs with no shells or with soft shells.

Oliveira (2002) observed that well-debeaked quails had better performance and easier access to nipple drinkers, as well as lower mortality and less incidence of aggressive behavior, as compared to those submitted to poor beak trimming practices.

There are recommendations on beak trimming practices in order to obtain the best results, but these are controversial due to the lack of accuracy in the description of the operation.
Due to the lack of information on quail beak trimming and on the necessary care to obtain good results, this study aimed at evaluating the effect of age and type of beak trimming on feathering, performance, and egg quality of quails during lay.

\section{MATERIAL AND METHODS}

A total number of 720 Japanese quail females, reared under identical management conditions, and receiving feed and water ad libitum, was used. Quails were housed and reared from 1 to 35 days of age on litter pens in a quail rearing house, after which birds were transferred to a quail masonry production house, being 4.0-m wide, and 12.0-m long. House sides had $0.50 \mathrm{~m}$-high walls, and $1.50 \mathrm{~m}$-high wire mesh, closed ceilings, lateral curtains, and tile roof. Birds were housed in $100 \mathrm{~cm}$-long, $34 \mathrm{~cm}$-deep, and $16 \mathrm{~cm}$-high cages, which contained four $25-\mathrm{cm}$ internal compartments, which allowed housing 20 quails per cage. Each compartment was equipped with a nipple drinker and a trough feeder located at the front of the cage.

Natural and artificial light were provided 17 hours per day, and an automatic clock was used to control light period during the entire experiment. $M$ aximal and minimal temperatures were daily recorded by a thermometer located in the central part of the house. Data collection started when quails were 49 days of age, and lasted for 112 days, divided into four periods of 28 days each.

Feeds were formulated on corn and soybean meal basis according to NRC (1994) recommendations, and considering raw material composition described by Rostagno et al. (2000). Feeds are shown in Table 1. Feed was manually offered three times per day ad libitum, and residues were weekly measured.

Eggs from each replicate were daily collected and counted to evaluate egg production. Eggs and feed residues were weekly measured for performance evaluation. The following parameters were evaluated: egg w eight ( $\mathrm{g}$ ), lay percentage (\% Lay), egg mass (EM), feed intake (FI), mortality (\%), and feed conversion ratio (FCR) per dozen eggs and per kg eggs.

A completely randomized experimental design was used, with six treatments in a $2 \times 3$ factorial arrangement, with two beak trimming ages (14 and 21 days) and three beak trimming variants (nontrimmed, $1 / 3$ of the beak trimmed, or $1 / 2$ of the beak trimmed). There were six replicates per treatment and 20 birds per replicate (Table 2 ). 
Pizzolante CC, Garcia EA, Saldanha ESPB, Laganá C, Faitarone ABG, Souza HBA, Pelicia K
Beak Trimming Methods and Their Effect on the Performance and Egg Quality of Japanese Quails (Coturnix japonica) During Lay

\begin{tabular}{|c|c|}
\hline \multicolumn{2}{|c|}{$\begin{array}{l}\text { Table } 1 \text { - Ingredient and nutrient composition of the experi- } \\
\text { mental feed. }\end{array}$} \\
\hline Ingredient & Experimental feed $(\mathbf{k g})$ \\
\hline Ground corn & 56,33 \\
\hline Soybean meal & 33,32 \\
\hline Soapstock & 2,86 \\
\hline Limestone & 5,35 \\
\hline Dicalcium phosphate & 1,31 \\
\hline Salt ( $\mathrm{NaCl})$ & 0,35 \\
\hline M ineral|(1) and vitamin ${ }^{(2)}$ supplements & 0,30 \\
\hline D-L Methionine & 0,14 \\
\hline Choline & 0,04 \\
\hline Total & 100,00 \\
\hline \multicolumn{2}{|l|}{ Nutrients } \\
\hline Crude protein (\%) & 20 \\
\hline M etabolizable energy ( $\mathrm{kcal} / \mathrm{kg}$ feed) & 2900 \\
\hline Calcium (\%) & 2,5 \\
\hline Available phosphorus (\%) & 0,350 \\
\hline Methionine $(\%)$ & 0,450 \\
\hline Methionine+cystine (\%) & 0,760 \\
\hline Lysine & 1,070 \\
\hline \multicolumn{2}{|c|}{$\begin{array}{l}1 \text { - M ineral supplementation per kg feed: copper: } 8 \mathrm{mg} \text {; iron: } 50 \mathrm{mg} \text {; } \\
\text { manganese: } 70 \mathrm{mg} \text {; zinc: } 50 \mathrm{mg} \text {; iodine: } 1,2 \mathrm{mg} \text {; selenium: } 0,2 \mathrm{mg} .2 \\
\text { - Vitamin supplementation per } \mathrm{kg} \text { feed: vitamin } \mathrm{A}: 7,000 \mathrm{IU} \text {; vitamin } \\
\text { D3: } 2,000 \mathrm{IU} \text {; vitamin } \mathrm{E}: 5 \mathrm{mg} \text {; vitamin } \mathrm{K} 3: 1.6 \mathrm{mg} ; \text { vitamin } \mathrm{B} 2: 3 \mathrm{mg} \text {; } \\
\text { vitamin B12: } 8 \mathrm{mcg} \text {; niacin: } 20 \mathrm{mg} \text {; pantothenic acid: } 5 \mathrm{mg} \text {; antioxidant: } \\
15 \mathrm{mg} \text {. }\end{array}$} \\
\hline
\end{tabular}

Egg quality was checked at the end of each 28-d period. Two eggs per replicate were removed for three consecutive days, with a total 36 eggs per treatment. Eggs were identified according to treatment, and individually weighed in digital scale with a 0.001 precision. Egg were then submitted to the laboratory to determined specific gravity (SG), yolk (\% Y), albumen $(\% \mathrm{~A})$, and eggshell (\%ES) percentages.

Specific gravity was determined according to the method of Padron (1991), in which eggs are immersed in saline solution with know $n$ densities, which vary from 1.065 to $1.100 \mathrm{~g} / \mathrm{cm}^{3}$ and a gradient of 0.005 , as determined by densitometer. Eggs were successively immersed in recipients containing the saline solution with decreasing densities. Egg specific gravity was considered the lowest density solution in which the egg floated.

Eggs were broken, shell, albumen, and yolk components were separated and individually weight in a 0.001 precision scale.
After washed in water and dried in forcedcirculation oven at $60{ }^{\circ} \mathrm{C}$ for $12 \mathrm{~h}$, eggshell thickness was determined in three different regions using a Mituyoto caliper, with $0.01-\mathrm{mm}$ precision, and according to the method described by Souza et al. (1984).

Yolk, albumen, and eggshell percentages were obtained by dividing the weight of each component by egg weight before it was broken.

Feathering was evaluated by the visual inspection of feather coverage on the back of the quails.

The experimental period lasted 112 days.

Data were submitted to analysis of variance (ANOVA) of the GLM procedure of SAS (1996) statistical package. Means were compared by the test of Tukey at a $5 \%$ significance level.

\section{RESULTS AND DISCUSSION}

Average minimal and maximal house temperatures during the experimental period were 18.6 and $28.4{ }^{\circ} \mathrm{C}$, respectively.

Performance results are presented in Table 3.

There were no significant interactions between age at beak trimming and trimming variants ( $p>0.05$ ). beak trimming variant had a significant effect on egg weight, lay percentage, egg mass, feed intake, feed conversion ratio per dozen eggs and per $\mathrm{kg}$ eggs $(p<0.01)$, with the best results obtained in non-trimmed and $1 / 3$ of the beak trimmed quails.

These results are consistent with those of Leandro et al. (2005), who observed that quails submitted to severe beak trimming obtained lower gains during the rearing phase. Araújo et al. (2005) and Sakomura et al. (1997) studied the effect of beak trimming in layer chickens, and found a reduction in weight gain in beaktrimmed birds as compared to those not submitted to beak trimming. The lower weight gains obtained by birds submitted to mild and severe beak trimming are justified by the stress produced by the procedure, which possibly caused pain and impairs feed ingestion, as reported by Kuo et al. (1991).

\begin{tabular}{cccc}
\hline $\begin{array}{c}\text { Table 2 } \text { - Treatments. } \\
\text { Treatments }\end{array}$ & Quail age(days) & Beak trimming & Diameter* of trimmed orifice* (mm) \\
1 & 14 & No trimming & - \\
2 & 14 & $1 / 3$ trimmed & $(2.778 \mathrm{~mm})$ \\
3 & 14 & $1 / 2$ trimmed & $(3.54 \mathrm{~mm})$ \\
4 & 21 & No trimming & - \\
5 & 21 & $1 / 3$ trimmed & $(3.54 \mathrm{~mm})$ \\
6 & 21 & $1 / 2$ trimmed & $(3.90 \mathrm{~mm})$ \\
\hline
\end{tabular}

* Beak trimming was performed with a Lyon trimmer, and both higher and lower beak parts were simultaneously trimmed. 


\begin{tabular}{|c|c|c|c|c|c|c|}
\hline \multirow[b]{2}{*}{ Parameters } & \multicolumn{2}{|c|}{ Age at beak trimming (days) } & \multicolumn{3}{|c|}{ Beak trimming variant } & \multirow{2}{*}{$\begin{array}{c}\text { CV } \\
(\%)\end{array}$} \\
\hline & 14 & 21 & ND* & $1 / 3$ & $1 / 2$ & \\
\hline Egg weight (g) & 9.98 & 9.99 & $10.10^{\mathrm{a}}$ & $10.08^{a}$ & $9.77^{\mathrm{b}}$ & 1.86 \\
\hline Lay (\%) & 83.48 & 84.39 & $85.35^{a}$ & $85.24^{\mathrm{a}}$ & $81.21^{b}$ & 3.91 \\
\hline Egg mass $(g)$ & 8.36 & 8.46 & $8.65^{a}$ & $8.62^{\mathrm{a}}$ & $7.97^{b}$ & 3.64 \\
\hline Feed intake $(\mathrm{g})$ & $22.40^{\mathrm{b}}$ & $22.92^{\mathrm{a}}$ & $23.40^{\mathrm{a}}$ & $22.78^{a}$ & $21.80^{\mathrm{b}}$ & 3.26 \\
\hline Feed conversion ratio $(\mathrm{kg} / \mathrm{dz})$ & 0.35 & 0.35 & $0.35^{\mathrm{ab}}$ & $0.34^{b}$ & $0.37^{a}$ & 3.34 \\
\hline Feed conversion ratio $(\mathrm{kg} / \mathrm{kg})$ & 2.91 & 2.99 & $2.86^{\mathrm{b}}$ & $2.85^{b}$ & $3.13^{a}$ & 5.89 \\
\hline M ortality (\%) & 0.41 & 0.37 & 0.52 & 0.33 & 0.34 & 89.83 \\
\hline
\end{tabular}

Means followed by different letters in the same row, within each factor, are significantly different $(p<0.05)$ by the test of Tukey. ND* not submitted to beak trimming.

The effects of beak trimming on egg production were studied by several authors, with controversial results. In many studies, an increase in lay is observed when birds are beak-trimmed, which may be the result of lower mortality and lower incidence of pecked eggs due to less aggressive behavior. In addition, this may also be due to a better feed conversion ratio in layers submitted to mild beak trimming, as they are not able to select ingredients in the feed, thereby preventing feed wastage. Sakomura et al. (1997) observed lower egg production in debeaked layer chickens as compared to those with intact beaks. According to Beane et al. (1967), beak trimming delays layer sexual maturity, and therefore, beak-trimmed layers would present lower egg production at the beginning of lay. On the other hand, Andrade \& Carson (1975) and Lee (1980) did not observe significant differences in egg production between birds submitted or not to beak trimming. These results are different from those found in the present experiment, in which birds submitted to severe beak trimming (1/2 of the beak) showed lower egg production as compared to those that were not beak-trimmed and had only $1 / 3$ of the beak trimmed.

There were significant effects of age at beak trimming on feed intake $(P<0.05)$. Birds debeaked at 21 days of age had higher feed intake than those debeaked at 14 days of age.

Egg quality results are presented in Table 4.

Age at beak trimming influenced $(p<0.05)$ egg specific gravity, with birds submitted to beak trimming at 21 days of age presenting higher egg specific gravity as compared to those submitted to this procedure at 14 days of age.

Beak trimming variant did not affect $(p>0.05)$ eggshell quality. Therefore, the reduction in feed intake caused by this factor did not impair the ingestion of nutrients that determine eggshell quality.

At the end of the experimental period, birds submitted to different beak trimming variants at 14 or 21 days of age presented different feathering patterns on the back. Birds with intact beaks presented no feathers on the back, whereas those with $1 / 3$ of the beak trimmed presented $90 \%$ of the back covered with feathers, and birds with $1 / 2$ of the beak trimmed had the back completely covered with feathers. This indicated that quails with intact beaks pecks the feathers of their cage mates, leading to complete loss of feathers in the dorsal region, which may impair thermal regulation processes. These results are consistent with those of Leeson \& M orrison (1978) and Tauson \& Svensson (1980).

\section{CONCLUSIONS}

Based on the results obtained in the present study, it is recommended to submit quails to beak trimming either at 14 or 21 days of age.

\section{REFERENCES}

Andrade AN, Carson JR. The effect of age at and methods of debeaking on future performance of White Leghorn Pullets. Poultry Science 1975; 54:666-674.

\begin{tabular}{|c|c|c|c|c|c|c|}
\hline \multirow[b]{2}{*}{ Parameters } & \multicolumn{2}{|c|}{ Age at beak trimming (days) } & \multicolumn{3}{|c|}{ Beak trimming variant } & \multirow{2}{*}{$\begin{array}{c}\text { CV } \\
(\%)\end{array}$} \\
\hline & 14 & 21 & ND* & $1 / 3$ & $1 / 2$ & \\
\hline Specific gravity $(\mathrm{g} / \mathrm{mL})$ & $1.074^{b}$ & $1.075^{\mathrm{a}}$ & 1.075 & 1.074 & 1.074 & 0.14 \\
\hline Yolk (\%) & 29.06 & 28.81 & 29.03 & 28.97 & 28.81 & 4.32 \\
\hline Albumen (\%) & 60.98 & 61.06 & 60.83 & 60.96 & 61.27 & 2.20 \\
\hline Eggshell (\%) & 9.97 & 10.12 & 10.14 & 10.07 & 9.93 & 4.74 \\
\hline
\end{tabular}

Means followed by different letters in the same row, within each factor, are significantly different $(p<0.05)$ by the test of Tukey. ND* not submitted to beak trimming. 
Araújo LF, Café MB, Leandro NSM et al. Performance of layer hens submitted or not to different methods of the beak trimming. Ciência Rural 2005; 35(1):169-173.

Araújo LF. Efeitos de diferentes tipos de debicagem sobre 0 desempenho de poedeiras comerciais nas fases de cria e recria [Monografia]. Goiás (GO):UFG; 1997.

Beane WL, Siegel PB, Dawson JS. et al. Size of debeak guide and cauterization time on the performance of Leghorn chickens. Poultry Science 1967; 46:1232.

Buxadé-Carbó C. La galina ponedora: sistemas de explotacion y tecnicas de produccion. Castelo: Mundi Prensa; 1987. 377p.

Cloutier S, New berry RC, Forster CT, Girsberger KM. Does pecking at inanimate stimuli predict cannibalistic behaviour in domestic fowl? Applied Animal Behaviour Science 2000; 66:119-133.

Cunningham DL. Beak trimming effects on performance, behavior and welfare of chickens: a review. Journal Applied Poultry Research 1992; 1:129-134.

Gentle MJ. Beak trimming in poultry. Worlds Poultry Science Journal 1986; 42:268-275.

Hughes BO, Gentle MJ. Beak trimming of poultry: its implications for welfare. World's Poultry Science 1995; 51(1):51-61.

Kuo FL, Craig JV, M uir WM. Selection and beak trimming effects on behavior, cannibalism, and short term production traits in White Leghorn pullets. Poultry Science 1991; 70:1057-1068.

Leandro MSM, Vieira NS, Matos MS et al. Desempenho produtivo de codornas japonesas (Coturnix coturnix japonica) submetidas a diferentes densidades e tipos de debicagem. Acta Scientiarum. Animal Sciences 2005; 27(1):129-135.
Lee K. Long term effects of Marek's disease vaccination with cellfree Herpesvirus of turkey and age at debeaking on performance and mortality of WhiteLeghorns. Poultry Science 1980; 59:20022007.

Leeson S, M orrison WD. Effect of feather cover on feed efficiency in laying birds. Poultry Science 1978; 57:1094-1096.

NRC. National Research Council. Nutrient Requirements of Poultry. 8th rev. ed. Washington: National Academy Press; 1994.

North M O, Bell DD. M anual de producción avícola. $3^{\text {nd }}$ ed. M éxico: Editorial El Manual Moderno; 1993.

Oliveira BL. Manejo racional e produtividade das codornas. In: Simpósio Internacional de Coturnicultura, 1.; 2002; Lavras. MG. Anais... Lavras: UFLA; 2002. p.77-95.

Padron MEN. Calidad de cascarón em aves reproductoras pesadas. Avicultura Profesional 1991; 8:112-14.

Rostagno HS, Albino LFT, Donizete JL et al. Tabelas brasileiras para aves e suínos - Composição de alimentos e exigências nutricionais. Viçosa, M G: Universidade Federal de Viçosa; 2000. 141p.

Sakomura NK, M oreno S, Costa MJRP et al. Efeito da debicagem e do enriquecimento ambiental no desempenho de galinhas poedeiras. ARS Veterinária 1997; 13:59-67.

SAS Institute. User's guide: statistics. Cary, NC: SAS Institute; 1996.

Souza PA, Faleiros RRS, Souza HBA. Efeitos sobre a qualidade dos ovos. Avicultura Industrial 1984; 893:24-7.

Tauson R, Svensson SA. Influence of plumage condition on the hen's feed requirement. Swedish Journal Agricultural Research $1980 ; 10: 35-39$. 